\title{
Titanoclinohumite: A Possible Mineralogical Site for Water in the Upper Mantle ${ }^{1}$
}

\author{
T. R. McGetchin, ${ }^{2}$ L. T. Silver, and A. A. Chodos \\ Division of Geological Sciences, California Institute of Technology \\ Pasadena, California 91109
}

\begin{abstract}
Titanium-rich clinohumite and layered structure minerals are observed in kimberlite and as inclusions in pyropic garnets from the Moses Rock dike, a kimberlite-bearing breccia dike in San Juan County, Utah. Associated clinopyroxenes observed as inclusions within similar pyropes and also in kimberlite are estimated to have equilibrated at depths ranging from about 50 to $150 \mathrm{~km}$ at modest temperatures, generally less than $1000^{\circ} \mathrm{C}$. The presence of titanoclinohumite, a high-density hydrous phase, is of considerable interest as a possible site for volatiles in the earth's upper mantle. The dehydration of hydrous phases such as titanoclinohumite within the upper mantle (1) may provide water as a free phase, (2) could be important in the genesis of kimberlite and alkali-basalt magma, and (3) may be one means of producing a low-velocity zone in the upper mantle.
\end{abstract}

\section{INTRODUCTION}

Titanoclinohumite has been observed in thin sections and in heavy mineral concentrates from kimberlite collected at the Moses Rock dike in San Juan County, Utah. This dike is one of a cluster of breccia-filled kimberlite-bearing diatremes located in northeast Arizona and southeast Utah, which are known to contain rock and mineral fragments believed to be derived from a wide vertical column ranging from the surface extending into the upper mantle [Shoemaker, 1956, 1962; Watson, 1967; McGetchin, 1968a; McGetchin and Silver, 1968, 1969]. Kimberlite dikes and pipes characteristically contain abundant hydrous phases, such as serpentine, talc, mica, chlorite, amphibole, in addition to olivine, pyroxene, garnet, spinel, and other less abundant minerals. Kimberlite generally is believed to be emplaced as volatilerich multiphase (probably fluidized) systems [Davidson, 1964; Shoemaker, 1962; Watson, 1967; McGetchin, 1968a, b], directly from the upper mantle at depths of 100 to $200 \mathrm{~km}$ [O'Hara, 1967; McGetchin and Silver, 1968].

${ }^{1}$ Contribution 1647, Division of Geological Sciences, California Institute of Technology.

2 Air Force Institute of Technology, WrightPatterson AFB, Ohio 45433. Presently Dept. of Earth and Planetary Sciences, Massachusetts Institute of Technology.

Copyright (c) 1970 by the American Geophysical Union.
This implies significant local concentration of volatiles in the upper mantle and raises the question of where $\mathrm{H}_{2} \mathrm{O}$ might reside at depth. If bound in hydrous minerals, amphibole [Oxbrough, 1964], biotite and phlogopite [Kushiro et al., 1967] are prime candidates because these phases are commonly observed in kimberlite and peridotite.

It is our suggestion that humite group minerals, specifically, titanoclinohumites, may be an important mineralogical site for bound water in the upper mantle and may be more abundant than commonly recognized because of their similarity to olivine in optical, physical, and chemical properties. It is implied that decomposition of titanoclinohumite to olivine, rutile, or other titanium-rich phases such as ilmenite or geikielite and free volatiles may have played an important role in the genesis of kimberlite at the Moses Rock dike and may be an important upper mantle process.

\section{OCCURRENCE OF Titanoclinohumite at Moses Rock Dike}

Titanoclinohumite is observed in several textural modes at Moses Rock dike, as grains in kimberlite commonly associated with olivine and as mineral inclusions within pyropic garnets.

Kimberlite at Moses Rock dike is a highly serpentinized, mica-bearing, peridotite microbreccia consisting of millimeter-sized angular mineral fragments, mostly olivine and pyroxene, 
more rarely, garnet, spinel, and mica, with subordinate small rock fragments, all set in a fine-grained groundmass of serpentine, chlorite, and talc. Serpentine, talc, and chlorite constitute about $80 \%$ of the rock by volume. As a discrete mappable rock unit, kimberlite is rare, occupying only about $1 \%$ of the area within the dike.

Clinohumite grains in the kimberlite occur as individual angular fragments averaging $1 \mathrm{~mm}$ in size, and less commonly as intergrowths (epitaxial?) with olivine in a single grain. Olivine clasts in kimberlite generally are partly serpentinized; titanoclinohumite is similarly altered but to a somewhat lesser degree than the olivine. This is clearly demonstrated when olivine and clinohumite occur together in the same grain.

Chrome-rich pyropic garnets, up to about 5 $\mathrm{mm}$ in diameter occurring in kimberlite at Moses Rock, are concentrated at the surface of the ground in aprons of ejecta surrounding ant hills. Mineral inclusions within these garnets include olivine, clinopyroxene, orthopyroxene, rutile, geikielite, ilmenite, mica, and titanoclinohumite. One particularly interesting pyrope specimen contains olivine, mica (?), clinohumite, and geikielite within the same grain. Mineral chemistry of the garnets and a large suite of associated inclusions is described elsewhere [McGetchin, 1968a; McGetchin and Silver, 1968, 1969].

\section{Identification AND Composition}

Titanoclinohumite was identified optically in thin sections of kimberlite. It is distinguished from olivine in ordinary light because of its brownish-yellow color.

Four grains from heavy mineral concentrates were picked, mounted, and analyzed for major elements ( $\mathrm{Si}, \mathrm{Ti}, \mathrm{Cr}, \mathrm{Fe}, \mathrm{Mg}, \mathrm{Mn}$ ) with the Caltech microprobe (Table 1, analyses 1, 2, 3, 4). Data were reduced by the method of Bence and Albee [1968]. Grains from these separates were powdered and positively identified as clinohumite by X-ray diffraction.

The density of several titanoclinohumite grains was determined by buoyancy tests in calibrated heavy liquids to be $3.27 \pm 0.02$, identical within error limits to the density of the associated olivine.

The most distinctive feature of these analyses is their high $\mathrm{TiO}_{2}$ contents.
The $\mathrm{Mg} /(\mathrm{Mg}+\mathrm{Fe})$ range is similar to that observed in olivine grains from Moses Rock kimberlite ( 89 to 94 , in olivine); where olivine and clinohumite were observed to coexist in the same grain, both had approximately the same $\mathrm{Mg} /(\mathrm{Mg}+\mathrm{Fe})$ ratio. This is shown in the analyses of coexisting olivine and titanoclinohumite (see Table 1, analyses 5, 6 and 10, 11). It is also true of coexisting titanoclinohumite and olivine inclusions in pyrope (see Table 1, analyses 8 and 9 ).

Total water contents can only be estimated by difference of the oxide summation from $100 \%$, but suggested values are all between 1 and 2 wt $\%$, in agreement with available wet chemical data (Table 1, analysis 14). The fluorine content is assumed to be characteristically low, in accordance with other workers' observation on titanoclinohumite.

\section{Occurrences and Structure of Clinohumite}

Balk [1954] observed clinohumite at the Buell Park diatreme near Fort Defiance, Arizona, about 95 miles southeast of the Moses Rock dike. Chemical analyses of a Buell Park sample (Table 1, analysis 14) show that major chemical constituents fall within the ranges defined by the Moses Rock specimens analyzed so far. The principal anion in the Buell Park titanoclinohumite is hydroxyl ion, not fluorine.

Titanium-rich clinohumites containing $2.92 \%$ $\mathrm{TiO}_{2}$ have been reported from Bhandara District, India, in phlogopite and tremolite-bearing marble [Muthuswami, 1958]. In the southern Urals clinohumite containing $\mathbf{5 . 4 0 \%} \quad \mathrm{TiO}_{2}$ was described in association with low-titanium, forsterite-rich olivine by Borneman-Starynkevich and Myasnikiv [1950].

The crystal structures of the humite group minerals are currently under investigation. Gibbs and Ribbe [1969] and Jones et al., [1969] have shown that humite group minerals consist of units of $\mathrm{Mg}(\mathrm{F}, \mathrm{OH}) \mathrm{O}$ alternating with $\mathrm{Mg}_{2} \mathrm{SiO}_{3}$ (F, OH).

Machatschki [1930] suggested that Ti replaces $\mathrm{Si}$ in the humite series, but Deer et al. [1962, pp. 52, 53] argue that no apparent silica deficiency accompanies high titanium contents. Moses Rock titanoclinohumites are possibly slightly silica-deficient, but only by about 1 to $2 \%$, a value essentially at the error limits. Jones et al. [1969] suggest that titanium sub- 
UPPER MANTLE WATER SITE

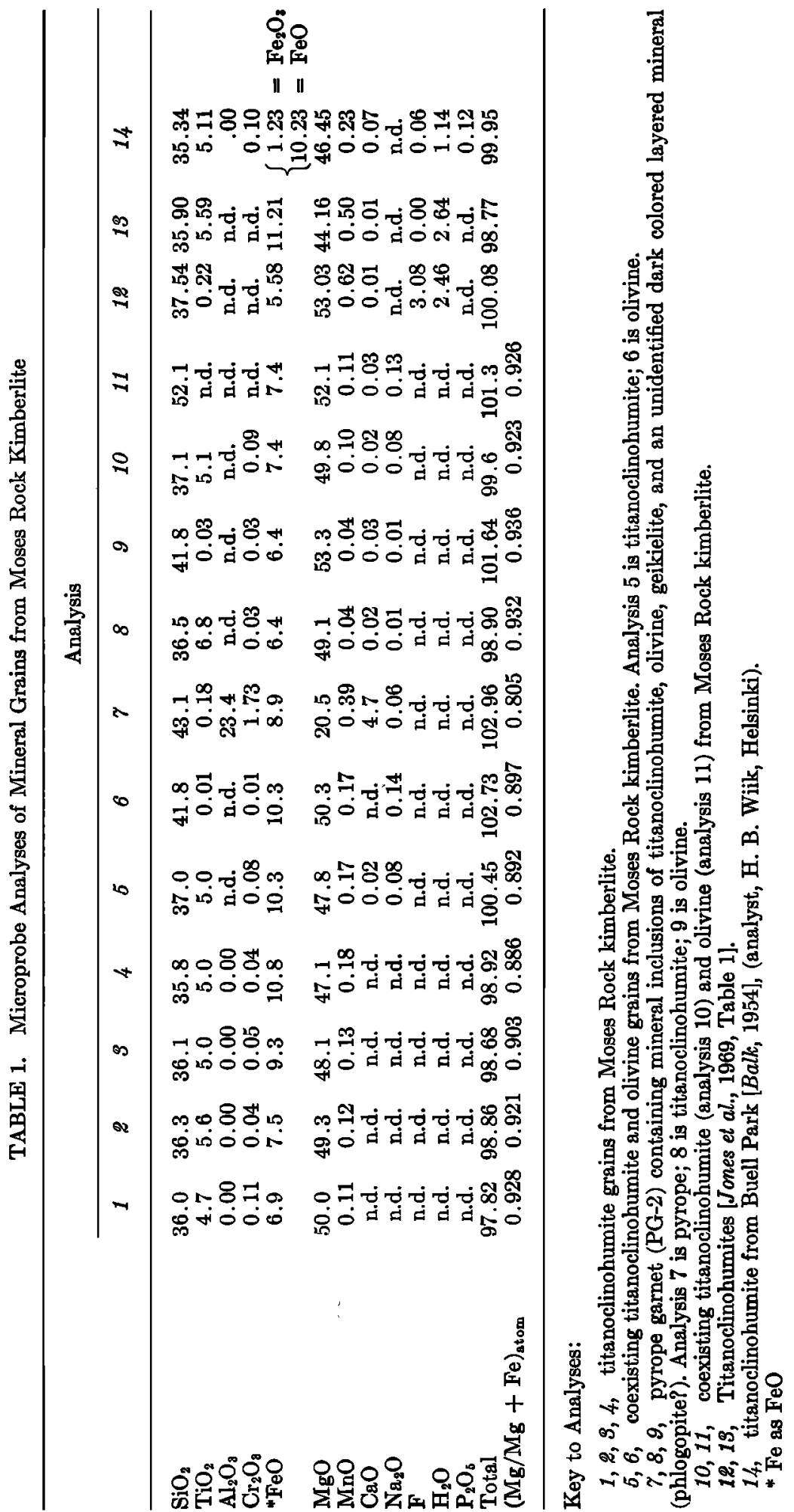


stitutes for $\mathrm{Mg}$ with a general humite formula of the form

$$
n\left[\mathrm{M}_{2} \mathrm{SiO}_{4}\right] \cdot\left[M_{1-x} \mathrm{Ti}_{x}(\mathrm{OH}, \mathrm{F})_{2-2 x} \mathrm{O}_{2 x}\right]
$$

where $x<1, M$ includes octahedral coordinated cations ( $\mathrm{Mg}, \mathrm{Fe}, \mathrm{Mn}, \mathrm{Ca}, \mathrm{Zn}$, etc.), and $n=4$ for clinohumite. This formula suggests that the ratios $\mathrm{Mg}: \mathrm{Ti}: \mathrm{Si}$ in clinohumites should vary systematically between $9: 0: 4$ (for $x=0$ ) and $8: 1: 4($ for $x=1)$.

Analysis of titanoclinohumites from Moses Rock kimberlite and other previously published analyses (Table 1) fall on the compositional join between $\mathrm{Mg}(\mathrm{OH}, \mathrm{F})_{2} \cdot 4 \mathrm{Mg}_{2} \mathrm{SiO}_{4}$ and $\mathrm{TiO}_{2}$ $\therefore 4 \mathrm{MgSiO}_{4}$, in agreement with the suggested formula of Jones et al. [1969], and exclude the possibility of $\mathrm{Ti}$ for Si substitution.

\section{Discussion and Conclusions}

The textural relationships almost preclude the genesis of titanoclinohumite in the Moses Rock kimberlite as a late stage alteration product of olivine and indicate that titaniclinohumite coexisted with chrome-pyrope and olvinie prior to serpentinization. Titanoclinohumite coexists with olivine of both higher and lower $\mathrm{Mg} /(\mathrm{Mg}$ $+\mathrm{Fe}$ ) ratios. Olivine grains separated from Moses Rock kimberlite have $\mathrm{Mg} /(\mathrm{Mg}+\mathrm{Fe})$ ratios between 88 and 94 . Samples with low $\mathrm{Mg} /(\mathrm{Mg}+\mathrm{Fe})$ ratios are believed to be derived from a spinel-bearing peridotite (lherzolite) assemblage with aluminum-rich pyroxenes; those with high $\mathrm{Mg} /(\mathrm{Mg}+\mathrm{Fe})$ ratios, from garnet-bearing peridotite (lherzolite) assemblage with aluminum-poor pyroxenes. Pressure and temperature estimates on mineral phases intimately associated with clinohumite in pyropes and in the kimberlite suggest that these minerals probably were derived directly from the mantle [McGetchin and Silver, 1968]. Minerals in kimberlite from the Moses Rock dike probably represent mechanically disintegrated lherzolite from the mantle, and to a much lesser extent from the vent walls, not crystals associated with a silicate melt [McGetchin, 1968a, 1969a]. It is inferred that titanoclinohumite was present with both garnet-bearing and-spinel-bearing assemblages in the mantle under the Moses Rock dike before transport to the surface during the emplacement of kimberlite.

The decomposition of hydrous minerals, such as titanoclinohumite, could supply part of the necessary volatiles responsible for the eruption and associated emplacement of kimberlite at Moses Rock dike. Rutile, chrome-bearing ilmenite, and geikielite are titanium-rich phases common among the dense minerals concentrated from Moses Rock kimberlite and could result from decomposition reactions involving titanoclinohumite, in part.

Liberation of free volatiles in the upper mantle by the decomposition of hydrous minerals including titanoclinohumite may be a geologically important pheonomenon and could be involved in the genesis of volatile-rich eruptive systems, such as kimberlite, carbonatites, and alkali-basalts, and may be a means of producing the low-velocity layer in regions of low surface heat flow where calculated upper mantle temperatures appear to be too low to permit partial melting.

Titanoclinohumite may be added to the list of possible volatile-bearing mineral phases within the mantle, along with phlogopite, amphibole, and hydrous pyroxenes.

Acknowledgments. Microprobe data were reduced with the help of Mrs. Lily Ray, with a computer program by A. L. Albee and A. E. Bence. The help of these individuals is gratefully acknowledged.

This research was supported by a Penrose grant (1940-65) from the Geological Society of America and the U.S. Atomic Energy Commission, contract AT(04-3) -427, CALT-427-40.

\section{REFERENCES}

Balk, R., Petrology section, in Mineral resources of Fort Defiance and Tohatchi quadrangles, Arizona and New Mexico, N. Mex. Bur. Mines Mineral Res. Bull. 36, 192, 1954.

Bence, A. E., and A. L. Albee, Empirical correction factors for the electron microanalysis of silicates and oxides, J. Geol., 76, 383-403, 1968.

Borneman-Starynkevich, I. D., and V. S. Myasnikiv, On isomorphous replacements in clinohumite, Dokl. Acad. Sci. USSR, 71, 137, 1950.

Davidson, D. F., On diamantiferous diatremes, Econ. Geol., 59, 1368-1380, 1964.

Deer, W. A., R. A. Howie, and J. Zussman, Rock Forming Minerals, vol. 1, Ortho- and Ring Silicates, John Wiley, New York, 1962.

Gibbs, G. V., and P. H. Ribbe, The crystal structures of the humite minerals, 1, Norbergite, Amer. Mineral., 54, 376-390, 1969.

Jones, N. W., P. H. Ribbe, and G. V. Gibbs, Crystal chemistry of the humite minerals, Amer. Mineral., 54, 390-411, 1969.

Kushiro, I., Y. Syono, and S. Akimoto, Stability of phlogopite at high pressure and possible 
presence of phlogopite in the earth's upper mantle, Earth Planet. Sci. Lett., 3, 197-203, 1967.

Machatschki, F., Ueber Titanolivin, Ein Beitrag zur Frage der Rolle des Titans in Silikatan, Centralb. Min., Abt. A, 191, 1930.

McGetchin, T. R., The Moses Rock dike: Geology, petrology, and mode of emplacement of a kimberlite-bearing breccia dike, San Juan County, Utah, Ph.D. thesis, California Institute of Technology, Pasadena, 1968a.

McGetchin, T. R., Structure of the Moses Rock kimberlite dike, San Juan County, Utah (abstract), Program Annual Meetings, Geological Society of America, Mexico City, 194-195, Nov. $1968 b$.

McGetchin, T. R., Source and emplacement of kimberlite at Moses Rock dike, Utah (abstract), Trans. Amer. Geophys. Union, 49, 360, $1969 a$.

McGetchin, T. R., A crustal-upper mantle model for the Colorado plateau based on observations of crystalline rock fragments in a kimberlite dike (abstract), Trans. Amer. Geophys. Union, $49,360,1969 b$.

McGetchin, T. R., and L. T. Silver, Compositional relations in kimberlite from the Moses Rock dike, San Juan County, Utah (abstract), Trans. Amer. Geophys. Union, 49, 360, 1968.

McGetchin, T. R., and L. T. Silver, Compositional relations in minerals from kimberlite and related rocks from the Moses Rock dike, San Juan County, Utah, submitted to American Mineralogist, 1969.
Muthuswami, T. N., Clinohumite, Sausar series, Bhandara District, India. Proc. Indian Acad. Sci., 48A, 9, 1958.

O'Hara, M. J., Mineral paragenesis in ultrabasic rocks, chap. 12, part III, in Ultramafic and Related Rocks, edited by P. J. Wyllie, John Wiley, New York, 1967.

Oxbrough, E. R., Petrological evidence for the presence of amplibole in the upper mantle and its petrogenic and geophysical implications, Geol. Mag., 101, 1, 1964.

Ribbe, P. H., G. V. Gibbs, and N. W. Jones, Cation and anion substitutions in the humite minerals, Mineral. Mag., s7, 966-975, 1968.

Shoemaker, E. M., Occurrence of uranium in diatremes on the Navajo and Hopi reservations, Arizona, New Mexico, and Utah, in Contributions to the Geology of Uranium and Thorium by the U.S. Geological Survey and Atomic Energy Commission for the United Nations Internation Conference on Peaceful Uses of Atomic Energy, Geneva, Switzerland, 1955, U.S. Geol. Surv. Prof. Pap., 300, 179-185, 1956.

Shoemaker, E. M., Interpretations of lunar craters, chap. 8, in Physics and Astronomy of the Moon, edited by Z. Kopal, Pergamon Press, New York, 1962.

Watson, K. D., Kimberlite pipes of northeastern Arizona, chap. 8, part IV, in Ultramafic and Related Rocks, edited by P. J. Wyllie, John Wiley, New York, 1967.

(Received July 11, 1969.) 